\title{
Effects of Kimchi Powder on Quality Characteristics of Semi-dried Pork Jerky
}

\author{
Kwang-Il An, Ji-Hun Choi ${ }^{1}$, Yun-Sang Choi ${ }^{1}$, Doo-Jeong Han, Hack-Youn Kim, \\ Mi-Ai Lee, Si-Young Kim, Tae-Hyun Kim, and Cheon-Jei Kim* \\ Department of Food Science and Biotechnology of Animal Resources, Konkuk University, Seoul 143-701, Korea \\ ${ }^{1}$ Research Institute for Meat Science and Culture, Konkuk University, Seoul 143-701, Korea
}

\begin{abstract}
This study was carried out to investigate the effects of kimchi powder addition on the quality properties of semi-dried pork jerky. Jerky was unamended (control) or was amended with dried kimchi powder to a concentration of 1\% (T1), 2\% (T2) or $3 \%$ (T3). The contents of moisture and ash were the highest in the T3 treatment. The protein content was highest in the control, but there was no significant difference in the fat content. The control exhibited the highest $\mathrm{pH}$ value, whereas $\mathrm{T} 2$ exhibited the lowest metmyoglobin content. The dry yield and water activity of T2 treatment were highest. There was no significant difference in the thiobarbituric acid value. Shear force was highest in the control. Overall, T2 produced a product with the best sensory evaluation results.
\end{abstract}

Key words: jerky, kimchi, kimchi powder, semi-dried, restructured

\section{Introduction}

Historically, jerky is one of the oldest types of meat products that are preserved via salting and drying to reduce their moisture content and water activity. It is convenient to eat, lightweight, shelf-stable when stored at room temperature, and nutritious, as it is high in protein and low in fat (Choi et al., 2008). Also, jerky is produced almost everywhere, and each product is unique (Kim et al., 2008). Beef jerky is more widely produced than jerky from the meat of other animals, but jerky can be made using several types of meats such as pork (Han et al., 2008), poultry (Pegg et al., 2006), ostrich (Lee and Kang, 2003).

Jerky has traditionally been made from sliced whole muscles of large animals that have been marinated and dried (Choi et al., 2008). Whole muscle jerky is very chewy, however, and has an undesirable over-dried color (Miller et al., 1996). Thus, it is important to address the tough texture of jerky. This problem may be solved using ground pork meat and additives. Several studies have

\footnotetext{
*Corresponding author: Cheon-Jei Kim, Department of Food Science and Biotechnology of Animal Resources, Konkuk University, Seoul 143-701, Korea. Tel: 82-2-450-3684, Fax: 82-2-444-6695, E-mail: kimcj@konkuk.ac.kr
}

been conducted to improve the textural properties of jerky that semi-dried type by increasing its moisture content (Choi et al., 2008) and adding humectants (sugar, konjac, egg albumin, isolated soy protein, and other carbohydrates) to it (Han et al., 2008; Kuo and Ockerman, 1985; Lim, 1992). Additionally, other researcher prepared jerky with restructured meat (Choi and An, 1996; Choi et al., 2007b, 2008) that lower price and efficient than whole muscle. Thus, manufacturers are saving production costs and can make the modification of the product size and shape for mass production.

Kimchi is a traditional fermented food and one of the most popular foods for side dishes in Korea (Lee et al., 2008). Chinese cabbage and radish are widely used as vegetables for kimchi, but various spices and minor ingredients (onion, green onion, cucumber, hot pepper, garlic, ginger, fermented shrimp, boiled starch, oyster, etc.) are also used to make it (Cheigh and Park, 1994). Many scientific studies have reported that kimchi is a healthy food and it is an antioxidant, has anti-cancer properties, and stimulates physiological activity (Hwang and Song, 2000; Lee and Kunz, 2005; Park, 2000), but its application to meat products is limited because it has a high moisture content (Lee et al., 2008). Kimchi has about $24.0 \%$ dietary fiber on a dry-weight basis after freeze-drying (Park et al., 1996). The higher fiber content in dried kimchi can be 
used to make fiber-enriched meat products for functional food consumption. Dietary fiber has an important role in the human diet, is nutritious, and has functional properties. Furthermore, dietary fiber has functional advantages such as its ability to increase the cooking yield due to its water- and fat-binding properties, and to improve food texture (Choi et al., 2007a, 2009; Cofrades et al., 2000).

Therefore, the objective of this study is to evaluate the effects of the addition of various kimchi powder levels to semi-dried pork jerky on the quality properties of the jerky.

\section{Materials and Methods}

\section{Kimchi and kimchi powder preparation}

Commercial Baechu (Chinese cabbage) kimchi, the style of central districts in Korea, was purchased from a local market (Chongga kimchi, Daesang FNF, Seoul, Korea). It was prepared as follows (\%); Chinese cabbages, cut into half heads, were dipped in $15 \%(\mathrm{w} / \mathrm{v})$ brine for $4 \mathrm{~h}$. The pieces of cabbage were washed with tap water, drained and then mixed with spices and additives. The recipe of ingredients and additives were; $68.1 \%$ salted Chinese cabbage, 16\% sliced radish, 6\% green onion, $2 \%$ onion, $1.6 \%$ scallion, $1.2 \%$ fermented shrimp, $1.2 \%$ fermented anchovy sauce, $2 \%$ red pepper powder, $1.2 \%$ chopped garlic, and $0.6 \%$ chopped ginger. At the beginning of fermentation, the $\mathrm{pH}$ of prepared kimchi averaged $\mathrm{pH}$ 5.4, and gradually decreased to $\mathrm{pH} 4.3$, packaged with PE/nylon film bags with sealing until approached the optimal sensory condition (Park and Lee, 2005 ) in a period of $15 \mathrm{~d}$ at $4 \pm 0^{\circ} \mathrm{C}$. The chemical composition of the kimchi, determined in triplicates according to the AOAC (1995) method, was: $91.3 \mathrm{~g} / 100 \mathrm{~g}$ moisture, $2.2 \mathrm{~g} / 100 \mathrm{~g}$ protein, $0.5 \mathrm{~g} / 100 \mathrm{~g}$ fat, $0.85 \mathrm{~g} / 100 \mathrm{~g}$ ash, and $2.1 \mathrm{~g} / 100 \mathrm{~g}$ dietary fiber. Fermented kimchi was blended with a cutter (C4 VV, Sirman, Marsango, Italy) and then packed with PE/nylon film. The blended kimchi was packed about $300 \mathrm{~g}$ of each bags and pressed flat for drying. The vacuum-packaged kimchi was immediately frozen at $-20 \pm 1^{\circ} \mathrm{C}$ until used. Kimchi was dried in a hot air dryer (Enex-Co-600, Enex, Yongin, Korea) at $60 \pm 1^{\circ} \mathrm{C}$. The samples were dehydrated until they reached a constant weight $(<15 \%$ final moisture) for $12 \mathrm{~h}$ at the hot air dryer, respectively, and then finely ground to $<0.5 \mathrm{~mm}$ (35 mesh) in size. The powders were stored in a deep freezer $\left(-70^{\circ} \mathrm{C}\right)$ until further used. All processing was done in triplicate.

\section{Preparation of semi-dried pork jerky containing kimchi powder}

Portions of $M$. biceps femoris, $M$. semitendinosus, $M$. semimembranosus in fresh pork were purchased from a local processor at $48 \mathrm{~h}$ after slaughter. All subcutaneous and intramuscular fat and visible connective tissue were removed from the fresh muscles. Lean meat was ground through an $8 \mathrm{~mm}$ plate. The composition (w/w) of jerky curing solution was water $(9.0 \%)$, soy sauce $(8.0 \%)$, starch syrup (3.31\%), sugar (1.8\%), D-sorbitol (5.8\%), pepper $(0.18 \%)$, ginger powder $(0.09 \%)$, garlic powder $(0.18 \%)$ onion powder $(0.18 \%)$, sodium nitrate $(0.005 \%)$ as a coupler, sodium citrate $(0.005 \%)$, potassium chlorate $(0.09 \%)$, sodium erythorbate $(0.03 \%)$, soup stock powder $(0.09 \%)$, meat stock $(0.3 \%)$, smoke flavor $(0.15 \%)$, teriyaki seasoning $(0.1 \%)$, humectant $(0.15 \%)$ and phosphate $(0.1 \%)$. And control sample was produced without the addition of powdered kimchi. Hot air-dried kimchi powder was incorporated into curing solution at levels of 1, 2, $3 \%$. The addition of sodium chloride was controlled as kimchi powder level because kimchi powder had 10\% salt content by adding $0.4 \%, 0.3 \%, 0.2 \%$ and $0.1 \%$ sodium chloride, respectively.

The manufacturing process of semi-dried pork jerky with kimchi powder is shown in Fig. 1. Meat was initially ground through an $8 \mathrm{~mm}$ plate and cut with a silent cutter (Cutter, Hermann Scharfen GmbH, Witten, Germany) for $1 \mathrm{~min}$. After adding salt and phosphate, meat was cut for an additional $2 \mathrm{~min}$. The ground meat were cured by tumbling with curing solution, and stuffed into cellulose casing $(20 \mathrm{~mm})$ for stick-type form. Each preparation was cut to $15 \mathrm{~cm}$-lengths. Semi-dried pork jerky with kimchi powder dried for $55^{\circ} \mathrm{C}(210 \mathrm{~min}) \rightarrow 65^{\circ} \mathrm{C}(210 \mathrm{~min}) \rightarrow$ $80^{\circ} \mathrm{C}(60 \mathrm{~min})$ in a hot air drier (Enex-CO-600, Enex, Yongin, Korea). Cellulose casing was removed from jerky at $60 \mathrm{~min}$.

\section{Compositional properties}

Compositional properties of the semi-dried pork jerky were measured using AOAC (1995). Moisture content was determined by weight loss after $12 \mathrm{~h}$ of drying at $105^{\circ} \mathrm{C}$ in a drying oven (SW-90D, Sang Woo Scienctific Co., Bucheon, South Korea). Fat content was determined by Soxhlet method with a solvent extraction system (Soxtec ${ }^{\circledR}$ Avanti 2050 Auto System, Foss Tecator AB, Höganas, Sweden) and protein content was determined by Kjeldahl method with an automatic Kjeldahl nitrogen analyzer (Kjeltec $® 2300$ Analyzer Unit, Foss Tecator AB, Höganas, Sweden). Ash was determined according to 


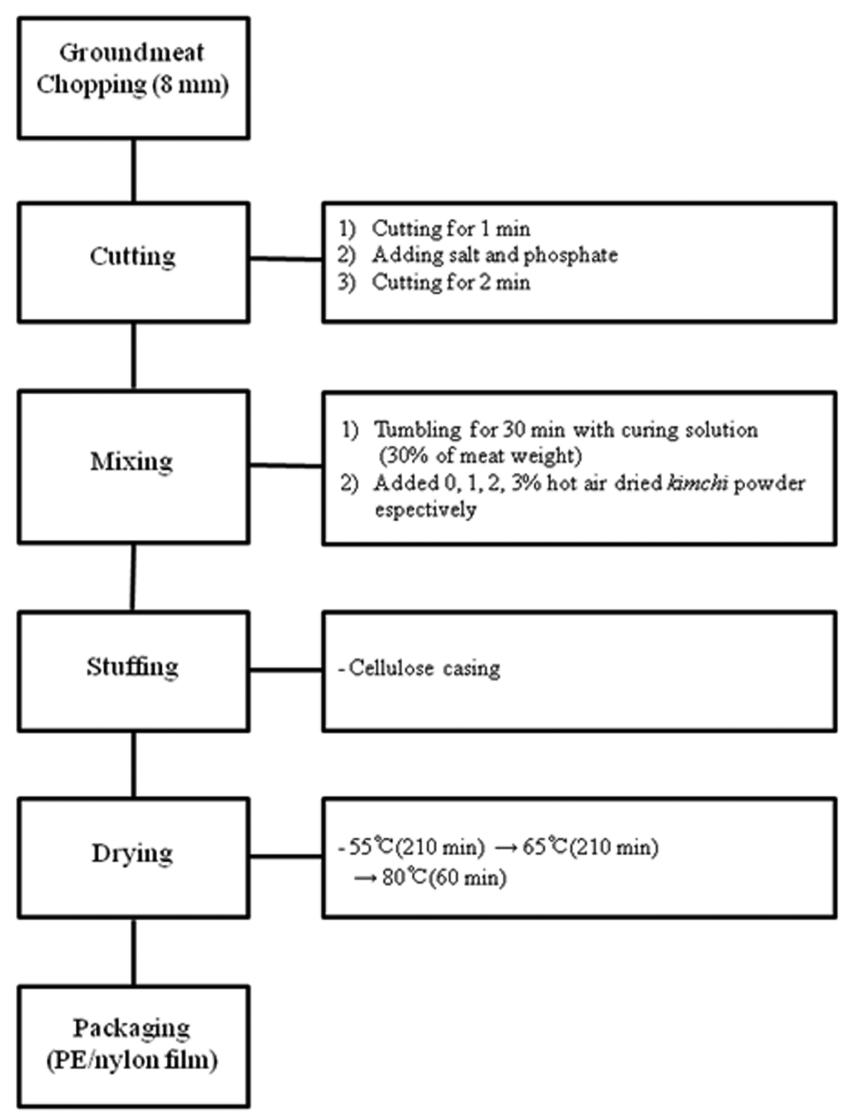

Fig. 1. Flow chart diagram for preparation of semi-dried pork jerky containing kimchi powder.

AOAC method (1995).

\section{Dry yields}

Dry yield was determined by calculating the weight differences of jerky before and after drying as follows:

Dry yield $(\%)=($ Jerky weight after drying

/Cured meat weight before drying) $\times 100$

\section{pH and water activity}

The $\mathrm{pH}$ of sample was determined with a $\mathrm{pH}$ meter (Model 340, Mettler-Toledo GmbH, Schwerzenbach, Switzerland) on a $5 \mathrm{~g}$ sample blended with $20 \mathrm{~mL}$ distilled water for $60 \mathrm{~s}$ in a homogenizer (Ultra-Turrax T25, Janke \& Kunkel, Staufen, Germany).

Samples for water activity were minced into pieces approximately $1 \mathrm{~mm} \times 1 \mathrm{~mm} \times 1 \mathrm{~mm}$ in size. The water activity of each sample was determined in duplicate with a hygrometer (BT-RS1, Rotronic ag., Bassersdorf, Switzerland).

\section{TBA (thiobarbituric acid) value}

The extent of lipid oxidation was determined by the
TBA (2-thiobarbituric acid) assay using the distillation method of Tarladgis et al. (1960) with minor modifications. A $10 \mathrm{~g}$ sample was blended with $50 \mathrm{~mL}$ distilled water for $2 \mathrm{~min}$ and then transferred to a distillation tube. The cup used for blending was washed with an additional $47.5 \mathrm{~mL}$ of distilled water, which was added to the same distillation flask with $2.5 \mathrm{~mL} 4 \mathrm{~N} \mathrm{HCl}$ and a few drops of an antifoam agent, silicone o/w (KMK-73, Shin-Etsu Silicone Co., Ltd., Seoul, Korea). The mixture was distilled and $50 \mathrm{~mL}$ distillate was collected. Distillates were reacted with TBA reagent $(0.02 \mathrm{M}$ TBA in $90 \%$ glacial acetic acid), and conventional spectrophotometric determination was performed at $538 \mathrm{~nm}$ using the UV/VIS spectrophotometer (Optizen 2120 UV plus, Mecasys Co., Ltd., Daejeon, Korea). TBA values were calculated from a standard curve $(8-50 \mathrm{nmol})$ of malondialdehyde (MA) freshly prepared by acidification of TEP (1,1,3,3-tetraethoxy propane). Reagents were obtained from Sigma (UK). The TBA levels were calculated as $\mathrm{mg} \mathrm{MA} / \mathrm{kg}$ sample.

\section{Percent metmyoglobin}

Metmyoglobin concentration of the semi-dried pork jerky was measured by a procedure described in Kryzwicki (1979) with a slight modification. Briefly, samples were blended with 5 volumes of cold $0.04 \mathrm{M}$ phosphate buffer at $\mathrm{pH} 6.8$ for $10 \mathrm{~s}$ in a homogenizer (Model AM-7, Nihonseiki Kaisha Ltd., Tokyo, Japan). After standing at $1^{\circ} \mathrm{C}$ for $24 \mathrm{~h}$, the mixtures were centrifuged at $3500 \mathrm{~g}$ at $4^{\circ} \mathrm{C}$ for $30 \mathrm{~min}$. The supernatant was further clarified by filtration through Whatman No. 1 filter paper. The absorbance of filtrate was measured at 525, 572, $700 \mathrm{~nm}$ using a spectrophotometer (Optizen III, Mecasys, Seoul, Korea). The percent metmyoglobin was calculated using the following formula:

$$
\begin{aligned}
& \text { Metmyoglobin }(\%) \\
& =\left[1.395-\left(\mathrm{A}_{572}-\mathrm{A}_{700}\right) /\left(\mathrm{A}_{525}-\mathrm{A}_{700}\right)\right] \times 100
\end{aligned}
$$

Where $\mathrm{A}_{\lambda}=$ Absorbance at $\lambda \mathrm{nm}$

\section{Shear force measurement}

The shear force value was determined with a WarnerBratzler shear attachment on a texture analyzer (TAXT2i, Stable Micro System Ltd., Surrey, UK). Test speeds was set at $2 \mathrm{~mm} / \mathrm{s}$. Data were collected and analyzed from the shear force values to obtain the maximum force required to shear through each sample and were then converted into $\mathrm{kg}$. 


\section{Sensory evaluations}

The semi-dried pork jerky processed with kimchi powders were subjected to sensory evaluations. The samples were served to 12 experienced panel members. Panelists were presented with randomly coded samples. The color ( 1 = extremely undesirable, $10=$ extremely desirable), flavor $(1=$ extremely undesirable, $10=$ extremely desirable $)$, tenderness $(1=$ extremely tough, $10=$ extremely tender $)$, juiciness $(1=$ extremely dry, $10=$ extremely juicy), and overall acceptability $(1=$ extremely undesirable, $10=$ extremely desirable) of the samples were evaluated using 10-point descriptive. Panelists were required to cleanse their palate between samples with water.

\section{Statistical analysis}

Analysis of variance was performed on all the variables measured using the General Linear Model (GLM) procedure of the SAS statistical package (SAS Institute, Inc., 1999). The Duncan's multiple range test $(p<0.05)$ was used to determine differences between treatment means.

\section{Results and Discussion}

\section{Proximate analysis of semi-dried pork jerky with kimchi powder}

The proximate compositions of semi-dried pork jerky with kimchi powder are shown in Table 1. The differences in the moisture, protein, and ash contents of the semidried jerky formulations were statistically significant ( $p$ $<0.05)$. The moisture content of the semi-dried jerky supplemented with $2 \%$ kimchi powder (T2) was higher than those of the other treatments $(p<0.05)$. Other researchers have reported significantly increased moisture contents of meat batters after the addition of fiber (Choi et al., 2007a; Lee et al., 2008). The increase in the moisture content could have been due to the increase in the water holding capacity due to the kimchi powder. In addition, Lee et al.
(2008) reported that the water absorption of kimchi powder was 311-409\% using different drying methods, and that the addition of kimchi powder increased the moisture contents of the jerky due to the water retention of the kimchi powder. Jose et al. (1994) reported that generally, commercial IM-food products have moisture contents of $20-40 \%$, and in his study, the contents ranged from 34 to $36 \%$. The fat content gradually increased as the level of the kimchi powder increased, but the differences among the treatments were not significant $(p>0.05)$. Other researchers have reported that the fat content of semi-dried jerky ranged from 18 to $20 \%$, as in this study. The protein content was significantly higher in the control than in the formulations with kimchi powder, except for the jerky with $1 \%$ kimchi powder (T1). The ash content increased as the kimchi powder level increased $(p<0.05)$, and was highest in the jerky that had 3\% kimchi powder (T3). These results are consistent with those reported by Lee $e t$ al. (2008), who indicated that the ash content significantly increased with the addition of dietary fiber to meat products.

\section{Dry yield of semi-dried pork jerky with kimchi powder}

The process of drying had a significant impact on the taste, flavor, texture, and color of the jerky. The drying was continued until the desired loss in weight, or $\mathrm{a}_{\mathrm{w}}$, was achieved. The dry yields of the semi-dried pork jerky samples that were prepared with various kimchi powder levels are shown in Fig. 2. The dry yield of the semi-dried pork jerky significantly increased as the level of kimchi powder that was added to it increased $(p<0.05)$. Kuo and Ockerman (1985) reported similar results with the dry yield of Chinese dried pork, which increased from $45 \%$ to $70 \%$, and Han et al. (2008) reported an increase from 47 to $50 \%$, as in this study. Similar studies have reported that the addition of fiber such as rice bran fiber (Choi et al.,

Table 1. Effects of kimchi powder level on compositional properties of semi-dried pork jerky

\begin{tabular}{lcccc}
\hline \hline \multicolumn{1}{c}{ Treatment } & Control & T1 & T2 & T3 \\
\hline Moisture (\%) & $34.27 \pm 0.51^{\mathrm{B}}$ & $35.33 \pm 1.43^{\mathrm{AB}}$ & $36.53 \pm 0.40^{\mathrm{A}}$ & $35.80 \pm 0.95^{\mathrm{AB}}$ \\
Crude fat (\%) & $19.95 \pm 1.51$ & $20.05 \pm 1.97$ & $20.26 \pm 2.22$ & $20.82 \pm 1.65$ \\
Crude protein (\%) & $38.60 \pm 0.54^{\mathrm{A}}$ & $38.35 \pm 0.27^{\mathrm{A}}$ & $37.37 \pm 0.19^{\mathrm{B}}$ & $37.12 \pm 0.60^{\mathrm{B}}$ \\
Crude ash (\%) & $4.49 \pm 0.02^{\mathrm{C}}$ & $4.51 \pm 0.10^{\mathrm{C}}$ & $4.78 \pm 0.04^{\mathrm{B}}$ & $5.07 \pm 0.07^{\mathrm{A}}$ \\
\hline
\end{tabular}

All values are mean \pm SD $(n=15)$.

${ }^{\mathrm{A}-\mathrm{C}}$ Means with different letters in the same row are significantly different $(p<0.05)$.

Control: No addition kimchi powder.

T1: Semi-dried pork jerky with $1 \%$ kimchi powder.

T2: Semi-dried pork jerky with $2 \%$ kimchi powder.

T3: Semi-dried pork jerky with 3\% kimchi powder. 


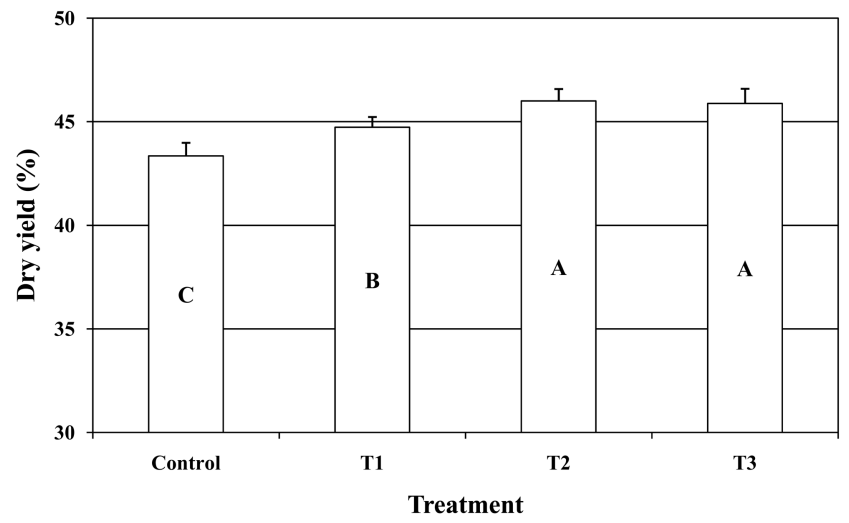

Fig. 2. Effects of kimchi powder level on dry yield of semidried pork jerky. ${ }^{\mathrm{A}-\mathrm{C}}$ Means in the treatment with different letters are significantly $(p<0.05)(\mathrm{n}=30)$. Control: No addition kimchi powder. T1: Semi-dried pork jerky with $1 \%$ kimchi powder. T2: Semi-dried pork jerky with $2 \%$ kimchi powder. T3: Semi-dried pork jerky with 3\% kimchi powder.

2007a), fruit fiber (Garcia et al., 2002), and carrot fiber (Eim et al., 2008) to meat products increased the dry yield and improved the meat's water and fat-binding properties. Consequently, kimchi powder is useful because of its ability to enhance the water and fat-binding properties of meat products.

\section{pH and water activity of semi-dried pork jerky with kimchi powder}

The $\mathrm{pH}$ and water activity values of semi-dried pork jerky that was prepared with different levels of kimchi powder are shown in Table 2 . The $\mathrm{pH}$ values of the semidried pork jerky with various kimchi powder levels ranged from 6.05 to 6.07 , with the control having the highest $\mathrm{pH}$ of $6.12(p<0.05)$. As more kimchi powder was added, the $\mathrm{pH}$ value decreased due to the basic $\mathrm{pH}$ of kimchi powder. Lee et al. (2008) obtained similar results in that the addition of kimchi powder decreased the $\mathrm{pH}$ value of the meat products in their study. Such result corresponded to the presence of organic acids in kimchi powder. In addition, Jose et al. (1994) reported that the average $\mathrm{pH}$ of the beef jerky in their study ranged widely from 4.72 to 6.73 ; Han et al. (2007) reported that the $\mathrm{pH}$ of the pork jerky in their study was 5.71-5.75; Lee et al. (2004) reported that the $\mathrm{pH}$ value of the gamma-irradiated semi-dried beef jerky in their study ranged from 5.81 to 5.85 .

The water activity values of the semi-dried pork jerky with various levels of kimchi powder varied from 0.81 to 0.82 , and all the jerky samples did not show significant differences. It is essential for intermediate-moisture (IM) meat products such as jerky to be dried to an acceptable $\mathrm{a}_{\mathrm{w}}$ level for proper shelf-life. Yamaguchi et al. (1986) reported that jerky must have a stable $\mathrm{a}_{\mathrm{w}}$ to avoid changes in its quality during its storage. The water activity, which is the measure of the free water present in food products, can sustain the growth of microorganisms (Choi et al., 2008). Therefore, water activity is important point in determining the microbial growth rate in meat products and the quality of the products during storage (Choi et al., 2007b).

TBA value and metmyoglobin percentage of semidried pork jerky with kimchi powder

The TBA value is consistent with sensorial properties in which lipid oxidation causes changes in the color, flavor, and texture of the meat product (Choi et al., 2010). The TBA values of the semi-dried pork jerky with various levels of kimchi powder are given in Table 2. The TBA values varied from 0.26 to $0.29 \mathrm{mg} / \mathrm{kg}$ and increased in proportion to the kimchi powder content, but all the jerky samples did not show significant differences. Yang and Lee (2002) reported that the initial TBA value of pork jerky is $0.239 \mathrm{mg} / \mathrm{kg}$, as in this study.

Metmyoglobin is brownish-grey in color and is mostly present in areas of low oxygen concentration between the oxygenated outer layers and the anaerobic inner areas of

Table 2. Effects of kimchi powder level on physicochemical properties of semi-dried pork jerky

\begin{tabular}{lcccc}
\hline \hline \multicolumn{1}{c}{ Treatment } & Control & T1 & T2 & T3 \\
\hline pH & $6.12 \pm 0.01^{\mathrm{A}}$ & $6.07 \pm 0.02^{\mathrm{B}}$ & $6.05 \pm 0.00^{\mathrm{C}}$ & $6.05 \pm 0.01^{\mathrm{C}}$ \\
Water activity & $0.80 \pm 0.01$ & $0.81 \pm 0.00$ & $0.82 \pm 0.01$ & $0.81 \pm 0.00$ \\
TBA (mg/kg) & $0.26 \pm 0.02$ & $0.27 \pm 0.03$ & $0.29 \pm 0.03$ & $0.29 \pm 0.04$ \\
Metmyoglobin (\%) & $85.59 \pm 1.12^{\mathrm{A}}$ & $81.36 \pm 0.54^{\mathrm{C}}$ & $81.02 \pm 0.40^{\mathrm{C}}$ & $83.46 \pm 0.25^{\mathrm{B}}$ \\
\hline
\end{tabular}

All values are mean $\pm \mathrm{SD}(\mathrm{n}=30)$.

${ }^{A-C}$ Means with different letters in the same row are significantly different $(p<0.05)$.

Control: No addition kimchi powder.

T1: Semi-dried pork jerky with $1 \%$ kimchi powder.

T2: Semi-dried pork jerky with $2 \%$ kimchi powder.

T3: Semi-dried pork jerky with 3\% kimchi powder. 
meat. Such color of meat products is commonly seen in meat product displays and is not attractive to consumers because it shows that the meat product is no longer fresh. In restructured meat products, myoglobin denaturation is affected by grinding, mixing, and multiplication of microorganisms (Govindarajan et al., 1977) and increase in temperature (Hood, 1980; Sherwin and Labuza, 2003), salt (Huffman et al., 1981; Rhee et al., 1983; Trout, 1989), and peroxide from lipid oxidation (Faustman and Cassens, 1990). The percent metmyoglobin of the semidried pork jerky samples that were prepared with various kimchi powder levels are shown in Table 2. They ranged from 81 to $83 \%$, with the control having the highest value of $85 \%(p<0.05)$. Thus, kimchi powder is effective in metmyoglobin denaturation, and improves the visual manifestation of the sensorial properties of jerky. Choi et al. (2008) reported that the percent metmyoglobin of semi-dried pork jerky prepared with various pork/beef levels and casings ranged from 85 to $89 \%$.

\section{Shear force values and sensory properties of semi- dried pork jerky with kimchi powder}

Texture is an important sensorial property of jerky for consumers (Kim et al., 2008). Shear force is the force needed to change the form of food, and is correlated with water activity, moisture content, cooking yield, and muscle fiber composition (Choi et al., 2007a, 2008). The shear force values of the semi-dried pork jerky samples with various levels of kimchi powder are shown in Fig. 3. The shear force value of the control was significantly higher $(p<0.05)$. Overall, as the kimchi powder content increased, the shear force value gradually decreased ( $p$ $<0.05)$. Similar researches reported that the addition to jerky of rice bran fiber (Choi et al., 2009); paprika and Japanese apricot extracts (Oh et al., 2007); and pear, pineapple, and kiwi extracts (Yang, 2006) decreased the

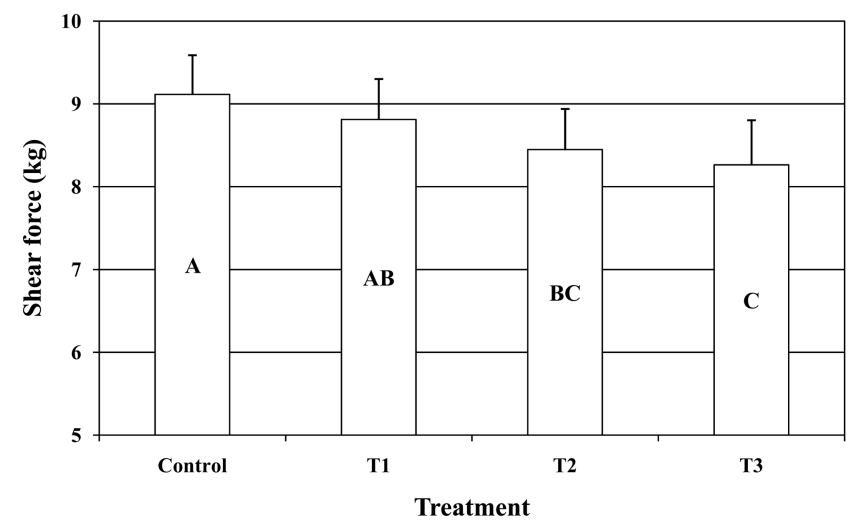

Fig. 3. Effects of kimchi powder level on shear force of semidried pork jerky. ${ }^{\mathrm{A}-\mathrm{C}}$ Means in the treatment with different letters are significantly $(p<0.05)(n=30)$. Control: No addition kimchi powder. T1: Semi-dried pork jerky with $1 \%$ kimchi powder. T2: Semi-dried pork jerky with $2 \%$ kimchi powder. T3: Semi-dried pork jerky with 3\% kimchi powder.

texture value of the jerky. The jerky in this study was produced with semi-dried type and using ground pork, so it had a lower shear force value than other sliced wholemuscle jerky products or low-moisture jerky products.

The sensory evaluations of the semi-dried pork jerky samples that were prepared with various levels of kimchi powder are shown in Table 3. The semi-dried pork jerky that was prepared with $2 \%$ kimchi powder (T2) scored significantly higher in color than the control jerky and the other jerky samples that were prepared with kimchi powder $(p<0.05)$, although there was no significant difference in their flavor, tenderness, and juiciness $(p>0.05)$. The semi-dried pork jerky that was prepared with $2 \%$ kimchi powder (T2) had the highest overall acceptability score ( $p$ $<0.05)$. A similar result was obtained by Lee et al. (2008). In addition, the semi-dried pork jerky that was prepared with 3\% kimchi powder (T3) scored lower than the jerky with $2 \%$ kimchi powder (T2), seemingly due to

Table 3. Effects of kimchi powder level on sensorial properties of semi-dried pork jerky

\begin{tabular}{llcc}
\hline \hline \multicolumn{1}{c}{ Treatment } & Control & T1 & T2 \\
\hline Color & $7.67 \pm 0.71^{\mathrm{C}}$ & $7.78 \pm 0.67^{\mathrm{BC}}$ & $8.56 \pm 0.88^{\mathrm{A}}$ \\
Flavor & $7.56 \pm 0.53$ & $7.67 \pm 0.71$ & $8.22 \pm 0.83$ \\
Tenderness & $7.33 \pm 0.87$ & $7.67 \pm 0.71$ & $8.00 \pm 0.71$ \\
Juiciness & $7.33 \pm 1.12^{\mathrm{AB}}$ & $7.44 \pm 1.01$ & $7.67 \pm 1.00$ \\
Overall acceptability & $7.56 \pm 0.53^{\mathrm{B}}$ & $7.78 \pm 0.67^{\mathrm{AB}}$ & $7.44 \pm 0.53$ \\
\hline
\end{tabular}

All values are mean \pm SD $(n=30)$.

${ }^{\text {A-C }}$ Means with different letters in the same row are significantly different $(p<0.05)$.

Control: No addition kimchi powder.

T1: Semi-dried pork jerky with $1 \%$ kimchi powder.

T2: Semi-dried pork jerky with $2 \%$ kimchi powder.

T3: Semi-dried pork jerky with 3\% kimchi powder. 
the properties of kimchi powder, such as its too strong sour and spicy taste.

In conclusion, the results of this study showed that semi-dried pork jerky prepared with kimchi powder improved the percent metmyoglobin, dry yield, shear force, and sensorial properties of the jerky. Especially, when semi-dried jerky was prepared with $2 \%$ kimchi powder, a good-quality semi-dried pork jerky with improved textural and sensorial properties was obtained. Thus, the addition of $2 \%$ kimchi powder can enhance the quality characteristics of semi-dried pork jerky.

\section{Acknowledgments}

This research was supported by Technology Development Program for Agriculture and Forestry, Ministry for Agriculture, Forestry and Ficheries (106115-02-1-SB010), Republic of Korea. The authors were also partially supported by the Brain Korea 21 (BK21) Project from the Ministry of Education and Human Resources Development.

\section{References}

1. AOAC (1995) Official methods of analysis (16th ed.). Washington, DC: Association of Official Analytical Chemists.

2. Cheigh, H. S. and Park, K. Y. (1994) Biochemical, microbiological, and nutritional aspects of kimchi (Korean fermented vegetable products). Crit. Rev. Food Sci. Nutr. 34, 175-203.

3. Choi, J. H., Jeong, J. Y., Han, D. J., Choi, Y. S., Kim, H. Y., Lee, M. A., Lee, E. S., Paik, H. D., and Kim, C. J. (2008) Effects of pork/beef levels and various casings on quality properties of semi-dried jerky. Meat Sci. 71, 278-286.

4. Choi, Y. I. and An, K. Y. (1996) Effects of phosphate type and addition level on binding ability, microstructure and storage characteristics of restructured pork jerky. Korean Soc. Anim. Sci. Technol. 38, 159-170.

5. Choi, Y. S., Choi, J. H., Han, D. J., Kim, H. Y., Lee, M. A., Jeong, J. Y., Chung, H. J., and Kim, C. J. (2010) Effects of replacing pork back fat with vegetable oils and rice bran fiber on the quality of reduced-fat frankfurters. Meat Sci. 84, 557563.

6. Choi, Y. S., Choi, J. H., Han, D. J., Kim, H. Y., Lee, M. A., Kim, H. W., Jeong, J. Y., and Kim, C. J. (2009) Characteristics of low-fat meat emulsion systems with pork fat replaced by vegetable oils and rice bran fiber. Meat Sci. 82, 266-271.

7. Choi, Y. S., Jeong, J. Y., Choi, J. H., Han, D. J., Kim, H. Y., Lee, M. A., Shim, S. Y., Paik, H. D., and Kim, C. J. (2007a) Quality characteristics of meat batters containing dietary fiber extracted from rice bran. Korean J. Food Sci. Ani. Resour. 27, 228-234.
8. Choi, Y. S., Jeong, J. Y., Choi, J. H., Han, D. J., Kim, H. Y., Lee, M. A., Paik, H. D., and Kim, C. J. (2007b) Effect of packaging methods on the quality properties of stick type restructured jerky. Korean J. Food Sci. Ani. Resour. 27, 290298.

9. Cofrades, S., Guerra, M. A., Carballo, J., Fernandes-Martin, F., and Colmenero, F. J. (2000) Plasma protein and soy fiber content effect on bologna sausage properties as influenced by fat level. J. Food Sci. 65, 281-287.

10. Eim, V. S., Simal, S., Rosselló, C., and Femenia, A. (2008) Effects of addition of carrot dietary fibre on the ripening process of a dry fermented sausage (sobrassada). Meat Sci. 80, 173-182.

11. Faustman, C. and Cassens, R. G. (1990) The biochemical basis for discoloration in fresh meat; A review. J. Muscle Foods. 1, 217-243.

12. Garcýìa, M. L., Dominguez, R., Galvez, M. D., Casas, C., and Selgas, M. D. (2002) Utilization of cereal and fruit fibers in low fat dry fermented sausages. Meat Sci. 60, 227-236.

13. Govindarajan, S., Hultin, H. O., and Kotula, A. W. (1977) Myoglobin oxidation in ground beef: mechanistic studies. $J$. Food Sci. 42, 571-577.

14. Han, D. J., Jeong, J. Y., Choi, J. H., Choi, Y. S., Kim, H. Y., Lee, M. A., Lee, E. S., Paik, H. D., and Kim, C. J. (2008) Effect of various humectants on quality properties of pork jerky. Korean J. Food Sci. Ani. Resour. 28, 486-492.

15. Han, D. J., Jeong, J. Y., Choi, J. H., Choi, Y. S., Kim, H. Y., Lee, M. A., Lee, E. S., Paik, H. D., and Kim, C. J. (2007) Effects of drying conditions on quality properties of pork jerky. Korean J. Food Sci. Ani. Resour. 27, 29-34.

16. Hood, D. E. (1980) Factors affecting the rate of metmyoglobin accumulation in pre-packaged beef. Meat Sci. 4. 247265.

17. Huffman, D. L., Ly, A. M., and Cordray, J. C. (1981) Effect of salt concentration on quality of restructured pork chops. $J$. Food Sci. 46, 1563-1565.

18. Hwang, J. W. and Song, Y. O. (2000) The effects of solvent fractions of kimchi on plasma lipid concentration of rabbit fed high cholesterol diet. J. Korean Soc. Food Nutr. 29, 204209.

19. Jose, F. S., Rafael, G., and Miguel, A. C. (1994) Water activity of Spanish intermediate-moisture meat products. Meat Sci. 38, 341-350.

20. Kim, J. M., Choi, J. H., Han, D. J., Choi, Y. S., Jeong, J. Y., Choi, G. H., Paik, H. D., and Kim, C. J. (2008) Effect of Protease Produced from Bacillus polyfermenticus SCD on quality of jerky. Food Sci. Biotechnol. 17, 389-395.

21. Kryzwicki, K. (1979) Assessment of relative content of myoglobin, oxymyoglobin and metmyoglobin at the surface of beef. Meat Sci. 3, 1-10.

22. Kuo, J. C. and Ockerman, H. W. (1985) Effect of salt, sugar and storage time on the microbiological, chemical and sensory properties of Chinese style dried pork. J. Food Sci. 50, 1384-1388.

23. Lee, J. Y. and Kunz, B. (2005) The antioxidant properties of baechu-kimchi and freeze-dried kimchi-powder in fermented 
sausages. Meat Sci. 69. 741-747.

24. Lee, M. A., Han D. J., Jeong, J. Y., Choi, J. H., Choi, Y. S., Kim, H. Y., Paik, H. D., and Kim, C. J. (2008) Effect of kimchi powder level and drying methods on quality characteristics of breakfast sausage. Meat Sci. 80, 708-714.

25. Lee, S. W. and Kang, C. S. (2003) Effects of moisture content and drying temperature on the physicochemical properties of ostrich jerky. Nahrung Food 47, 330- 333.

26. Lim, J. G. (1992) Effect of water activity on the quality and shelf-life of beef jerky. MS thesis, Korea University, Seoul, Korea.

27. Miller, M. F., Davis, G. W., Ramsey, C. B., and Irizarry, H. (1996) Water activity theory and application to food. In: L. B. Rockland and L. R. Beuchat (Eds). Marcel Dekker, New York, pp. 295-328.

28. Oh, J. S., Park, J. N., Kim, J. H., Lee, J. W., Byun, M. W., and Chun, S. S. (2007) Quality characteristics of pork jerky added with Capsicum annum L. and Prunus mume Sieb. et Zucc. extract. J. Korean Soc. Food Sci. Nutr. 36, 81-86.

29. Park, K. Y. (2000) Nutrition, function, and anticancer effect of kimchi. Kimchi Research Institute, Pusan National University, Pusan, Korea, pp. 124-131.

30. Park, K. Y., Ha, J. O., and Rhee, S. H. (1996) A study on the contents dietary fibers and crude fiber in kimchi ingredients and kimchi. J. Korean Soc. Food Nutr. 25, 69-75.

31. Park, S. H. and Lee, J. H. (2005) The correlation of physicchemical characteristics of kimchi with sourness and overall acceptability. Korean J. Soc. Food Cookery Sci. 21, 103-109.

32. Pegg, R. B., Amarowicz, R., and Code, W. E. (2006) Nutritional characteristics of emu (Dromaius novaehollandiae) meat and its value-added products. Food Chem. 97, 193-202.

33. Rhee, K. S., Terrell, R. N., Quintanilla, M., and Vanderzant, C. (1983) Effect of addition of chloride salts on rancidity of ground pork inoculated with a Moraxella or a Lactobacillus species. J. Food Sci. 48, 302-303.

34. SAS (1999) SAS user's guide: Basic statistical analysis. Cary, NC: SAS Inst.

35. Sherwin, C. P. and Labuza, T. P. (2003) Role of moisture in maillard browning reaction rate in intermediate moisture foods: comparing solvent phase and matrix properties. $J$. Food Sci. 68, 588-593.

36. Tarladgis, B. G., Watts, B. M., Younathan, M. T., and Dugan, L. (1960) A distillation method for the quantitative determination of malonaldehyde in rancid foods. J. Am. Oil Chemists' Soc. 37, 44-48.

37. Trout, G. R. (1989) The effect of calcium carbonate and sodium alginate on the color and bind strength of restructured beef steaks. Meat Sci. 25, 163-175.

38. Yamaguchi, N., Naito, S., Okada, Y., and Nagase, A. (1986) Effect of oxygen barrier of packaging material on food preservation. Ann. Report Food Res. Inst., Aichi Prefecture Government. 27, 69-73.

39. Yang, C. Y. (2006) Physicochemical properties of chicken jerky with pear, pineapple and kiwi extracts. The Korean $J$. Culinary Res. 12, 237-250.

40. Yang, C. Y. and Lee, S. H. (2002) A evaluation of quality of the marketing jerky in domestic - I. Investigation of outward appearance, food additives, nutrient content and sanitary state. Korean J. Food Nutr. 15, 197-202.

(Received 2009.10.15/Revised 2010.3.24/Accepted 2010.3.24) 